\begin{tabular}{|l|l|l||}
\hline \multicolumn{2}{|c|}{ PublisherInfo } \\
\hline \hline PublisherName & $:$ & BioMed Central \\
\hline \hline PublisherLocation & $:$ & London \\
\hline \hline PublisherImprintName & $:$ & BioMed Central \\
\hline \hline
\end{tabular}

\title{
Of cloned pigs and PERV
}

\begin{tabular}{|l|l|l||}
\hline \multicolumn{2}{|c|}{ ArticleInfo } \\
\hline \hline ArticleID & $:$ & 3746 \\
\hline \hline ArticleDOI & $:$ & $10.1186 /$ gb-spotlight-20000818-01 \\
\hline \hline ArticleCitationID & $:$ & spotlight-20000818-01 \\
\hline \hline ArticleSequenceNumber & $:$ & 183 \\
\hline \hline ArticleCategory & $:$ & Research news \\
\hline \hline ArticleFirstPage & $:$ & 1 \\
\hline \hline ArticleLastPage & $:$ & 2 \\
\hline \hline & & RegistrationDate : 2000-08-18 \\
ArticleHistory & $:$ & OnlineDate $\quad$ 2000-08-18 \\
\hline \hline ArticleCopyright & $:$ & BioMed Central Ltd2000 \\
\hline \hline ArticleGrants & $:$ & \\
\hline \hline ArticleContext & $:$ & 130591111 \\
\hline \hline
\end{tabular}


William Wells

Email: wells@biotext.com

Nuclear microinjection has yielded the first pig clones, but the wisdom of using the clones as xenotransplant donors is in doubt based on transmission of a pig retrovirus to immunocompromised mice. Onishi et al. report in the 18 August Science that they have used microinjection of a fetal cell nucleus into an enucleated oocyte to produce a single piglet clone dubbed Xena (Science 2000, 289:1188-1190). In a battle of the press embargoes, this led Nature, to reveal that they will soon be publishing a paper from a group at PPL Therapeutics that reports use of a double nuclear transfer procedure from cultured cells to produce a litter of five cloned piglets. But in the same issue of Nature, Daniel Salomon of the Scripps Research Institute and colleagues will report that a porcine endogenous retrovirus (PERV) can infect human cells in co-culture and, after transfer of pig pancreatic islets to immunocompromised mice, mouse cells in vivo. Although pig-derived xenotransplants would be less likely to be rejected after modification by gene targeting and cloning, the fear of transferring infectious agents may prompt some researchers to back off from xenotransplantation. Indeed, the upshot of some rather muddled comments from Ian Wilmut and Geron Bio-Med of Dolly fame appears to be a decision to abandon their pig xenotransplantation program.

\section{References}

1. Science Magazine, [http://www.sciencemag.org/]

2. Nature, [http://www.nature.com/nature/]

3. PPL Therapeutics, [http://www.ppl-therapeutics.com]

4. The Scripps Research Institute, [http://www.scripps.edu]

5. Biotech firm Geron buys Roslin Bio-Med, the company formed by Scottish researchers who cloned Dolly the sheep. , [http://abcnews.go.com/sections/business/DailyNews/geron990505.html]

6. Sheep cloned by nuclear transfer from a cultured cell line. 